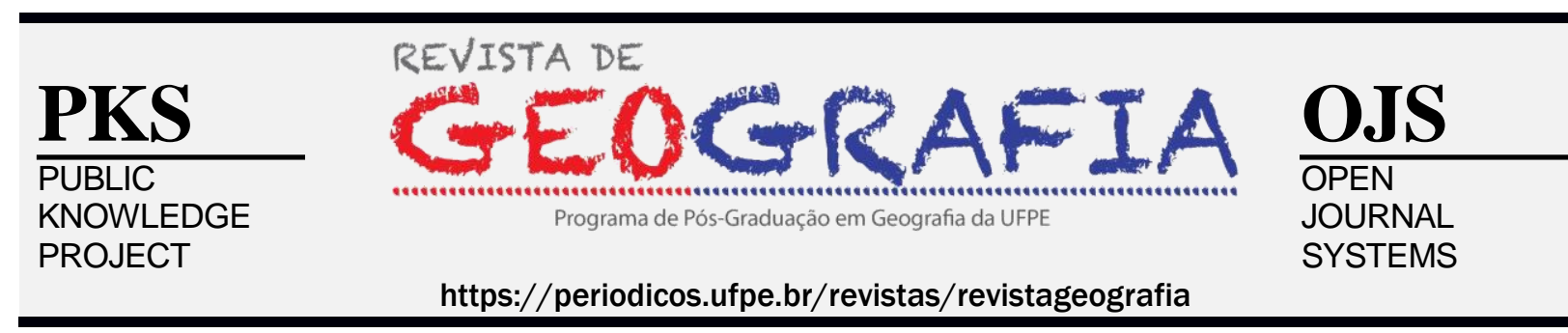

\title{
ROMARIA DA FLORESTA: A FÉ ENTRE TERRITORIALIDADES E RESISTÊNCIAS
}

\author{
José Marcelo Andrade Ferreira ${ }^{l}$ \\ ${ }^{1}$ Secretaria de Estado de Educação do Pará. E-mail: marcelo30.ap@hotmail.com \\ Artigo recebido em 03/08/18 e aceito em 11/04/19

\begin{abstract}
RESUMO
A Romaria da Floresta é uma manifestação religiosa e política, organizada pela Comissão Pastoral da Terra (CPT) e realizada no município de Anapu, no Estado do Pará. Surgiu após o assassinato da Missionária norteamericana Dorothy Stang e foi uma forma de denunciar a violência no espaço agrário do município e de homenageá-la. Seu itinerário possui diversas manifestações da cultura no espaço, como: lugares simbólicos, formas simbólicas e memoriais. Os lugares e formas simbólicas estão relacionados com a história de resistência do campesinato e com a história de vida da Missionária Dorothy Stang. O trabalho em questão trata de um estudo qualitativo, tendo, como instrumentais metodológicos, observações, entrevistas e revisão da literatura.
\end{abstract} \\ Palavras-chave: Romaria. Anapu. Lugares Simbólicos. Formas simbólicas. Conflitos.
}

\section{PILGRIMAGE OF THE FOREST: THE FAITH BETWEEN TERRITORALITES AND RESISTANCES IN THE MUNICIPALITY OF ANAPU, PARÁ.}

\section{ABRTRACT}

The Romaria da Floresta is a religious and political manifestation organized by the Pastoral Land Commission (CPT) and held in the municipality of Anapu in the State of Pará. The Pilgrimage came after the assassination of the American Missionary Dorothy Stang as a way of denouncing the violence in the agrarian space of the municipality and honoring the missionary. The itinerary includes various manifestations of culture in space, such as: symbolic places, symbolic forms and memorials. Symbolic places and forms are related to the peasantry's history of resistance and the life story of Missionary Dorothy Stang. This research is a qualitative study whose methodological instruments are observations, interviews, as well a literature review.

Keywords: Pilgrimage. Anapu. Symbolic places. Symbolic forms. Conflicts.

\section{APRESENTAÇÃO}

Este artigo é resultado da pesquisa realizada para o desenvolvimento de dissertação de mestrado intitulada "Romaria da Floresta: a fé entre territorialidades e resistências no município de Anapu-PA" e defendida no Programa de Pós-Graduação em Geografia, da Universidade do Estado do Rio de Janeiro (PPGEO-UERJ). 
A Romaria da Floresta é uma manifestação política e religiosa, organizada pela Comissão Pastoral da Terra e realizada há 13 anos no município de Anapu-PA. A primeira Romaria da Floresta ocorreu entre os dias 22 e 25 de julho de 2006, pouco mais de um ano após o seu assassinato, no dia 12 de fevereiro de 2005. Teve como consigna "Celebrar o compromisso de defender a vida da floresta, do povo e do planeta" e, a cada edição, elaborase uma consigna nova. A $12^{\mathrm{a}}$ edição teve como consigna "Chega de paciência! Até quando?", exigindo celeridade na regularização de terras e denunciando permanência da violência contra trabalhadores rurais no município (ROMARIAS..., 2018).

A romaria foi inserida no calendário das atividades ligadas ao Dia do Lavrador, que eram realizadas nos meses de julho em Anapu. Eram desenvolvidas atividades que reuniam Comunidades Eclesiais de Base (CEEBs), trabalhadores rurais e membros de pastorais, era um momento de formação política e celebração.

Figura 1- Localização geográfica do município de Anapu.

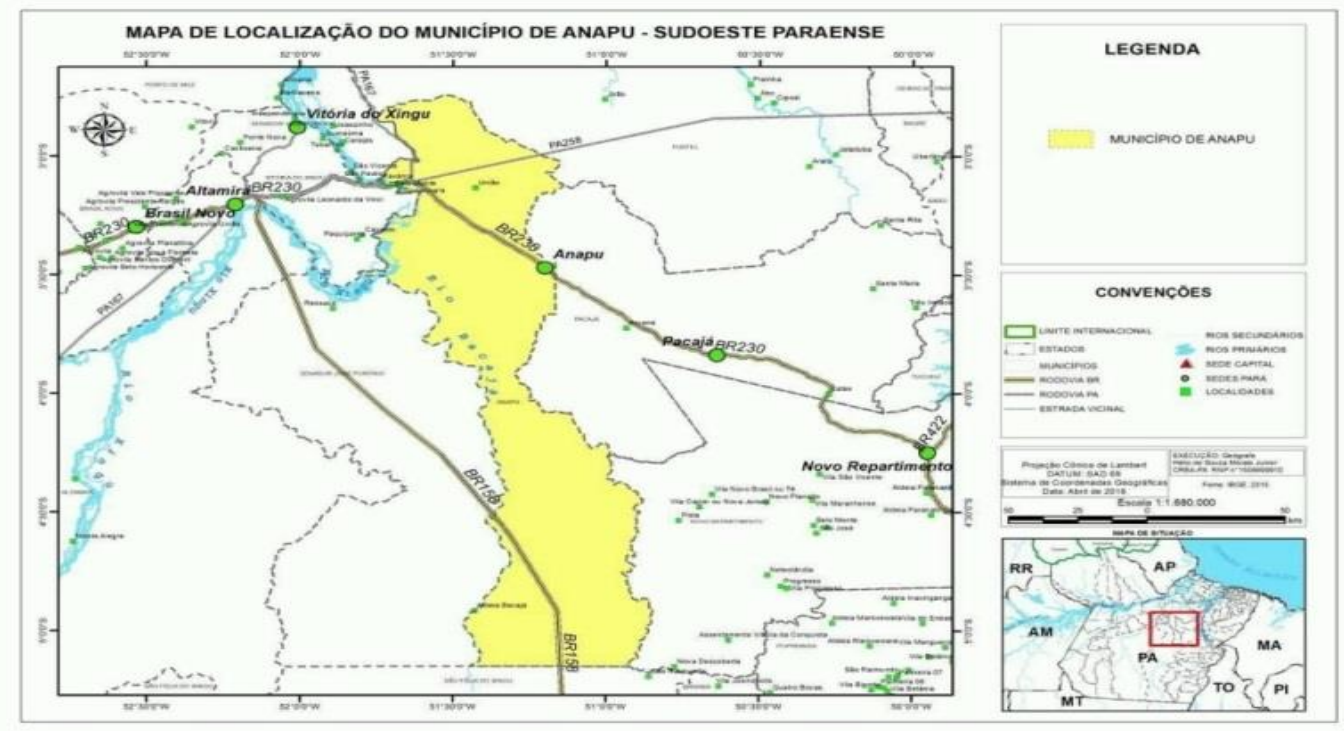

Fonte: Elaboração do autor, 2017.

O resgate da memória da Missionária e da resistência camponesa na Amazônia é constante no itinerário da Romaria da Floresta, seja através de depoimentos realizados nas paradas em lugares simbólicos ${ }^{1}$ ou com exibição de documentários e encenações teatrais. Em muitas falas, a Irmã Dorothy Stang recebe a designação de mártir da terra e da floresta.

\footnotetext{
${ }^{1}$ Esses lugares também podem ser considerados lugares de memória. Os "lugares de memória", expressão cunhada por Pierre Nora (1989), tem em suas representações materiais os memoriais que são também
} 
Expressões como "justiça socioambiental", "reforma agrária popular e sustentável” e "a morte da floresta é o fim da nossa vida" são proferidas no itinerário da Romaria. Romeiros de vários municípios do Pará e de outros estados do Brasil participam da peregrinação, além de entidades como MAB (Movimento dos Atingidos por Barragens), MST (Movimentos dos Sem Terra), CEBs (Comunidades Eclesiais de Base), sindicatos de trabalhadores rurais, Pastoral da Juventude, Pastoral dos Pescadores e até pesquisadores brasileiros e estrangeiros.

A Romaria da Floresta é uma manifestação recente na Amazônia paraense, mas alcançou visibilidade nacional e internacional. No entanto, ainda é carente de estudos, principalmente daqueles que dialoguem com abordagens culturais em geografia. Possui sua origem nos conflitos territoriais do município de Anapu, referência em conflitos agrários, assim como outros municípios paraenses.

Apresenta uma riqueza de simbolismos e práticas que se interligam à luta de homens e mulheres por acesso à terra e a direitos. Ao mesmo tempo, representa uma forma de a Igreja Católica Apostólica Romana garantir e ampliar sua territorialidade religiosa no município, principalmente através da atuação da CPT.

Um dia antes do início da peregrinação, ocorre a recepção dos romeiros, no Centro de Formação São Rafael, onde são desenvolvidas diversas atividades, como exibição de documentários que tratam da luta pela terra e seus mártires, debates, orações, místicas ${ }^{2}$ e a execução, por parte dos romeiros, principalmente os ligados à Pastoral da Juventude (PJ), de músicas do cancioneiro popular, sempre acompanhadas por instrumentos percussivos.

Essas sonoridades peregrinam durante os três dias que segue a romaria mas não serão abordadas no artigo. Na edição de 2017, foi marcante a presença de jovens, ligados às Pastorais da Juventude de vários municípios do Pará, e, segundo os organizadores, foi a edição com a maior presença de jovens. Nesta edição, a tarefa de divulgar da Romaria foi repassada para as pastorais da juventude de vários municípios do Estado do Pará. No trecho

\footnotetext{
objetos "abertas da diferentes interpretações e maleáveis de acordo com as necessidades de poder do Estado e forças religiosas" (...) são, assim, objetos cujos significados podem ser recriados e apropriados por instituições e grupos com motivações, práticas e interesses distintos (...) (CORRÊA, 2013, p. 83).
}

2 Mística é uma palavra derivada de mistério. Mistério em seu sentido pessoal não significa o limite do conhecimento, mas o ilimitado em todo conhecimento. Em todos os campos da experiência humana e cósmica topamos com o mistério. Ele é o outro lado e profundo de toda realidade. O órgão de sua captação é antes o coração que a mente (BOFF, 2008, p.183-184). 
selecionado do texto de divulgação da edição de 2017, é possível observar a menção a outros episódios de violência e a personagens considerados mártires. Assim se verifica na passagem abaixo:

\begin{abstract}
A Pastoral da Juventude do Regional Norte II (território que é nosso solo sagrado, historicamente regado com o sangue dos mártires e o suor da luta e resistência dos profetas da terra e da floresta) celebra 12 anos do martírio de Irmã Dorothy Stang, e faz memória dos 20 anos da chacina de Eldorado dos Carajás, dos 6 anos do assassinato do casal de extrativistas José Claudio e Maria do Espirito Santo, e presencia mais uma vez com indignação, mais uma chacina, desta vez na cidade de Pau D'arco, Sudoeste do Estado do Pará, no dia 24 de maio de 2017. Lança uma nota oficial, a qual convoca a juventude a refletir sobre os conflitos agrários em nosso regional, se posicionando em defesa dos menos favorecidos (ROMARIAS..., 2018).
\end{abstract}

Essa presença jovem imprimiu mudanças em relação a algumas práticas observadas na edição de 2015. A primeira mudança foi na sonoridade que peregrina junto com os romeiros. O rock com letras de protesto foi bastante executado em todo o itinerário da romaria; bandas como Titãs, Plebe Rude, Capital Inicial e Legião Urbana tiveram destaque na "Dorotéia", o carro (fusca) que pertencia à Missionária Dorothy Stang, no qual se adaptou alto-falantes. A "Dorotéia" é utilizada pelos romeiros para suas falas, orações, místicas e canções. Além disso, o carro também vai conduzindo a Romaria em todo o seu itinerário e, à frente dele, uma cruz, contendo a foto da Missionária Dorothy Stang, é carregada por romeiros, que se revezam na tarefa.

A juventude também realizou, no itinerário da Romaria, por aproximadamente 15 minutos, o "correio do amor", onde os recados foram lidos, sem citar nomes, com a menção apenas às características físicas e à pastoral a qual pertencia o destinatário da mensagem. A presença jovem também trouxe inovações em relação à acomodação dos romeiros, pois, na edição de 2017, surgiu um acampamento com barracas, sendo que, até então, o que predominavam eram as redes. Uma observação que merece destaque está relacionada ao consumo de bebidas alcoólicas no Forró da Dorothy, que, ao contrário da edição de 2015, foi tolerado. 
Figura 2 - Dorotéia: o carro que pertencia à Missionária.

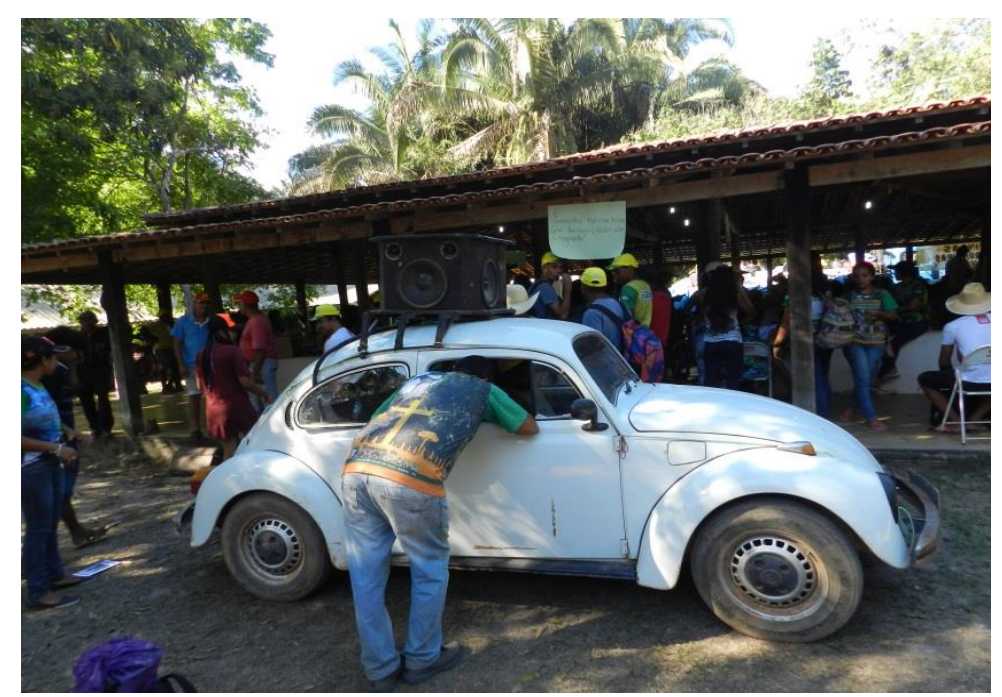

Fonte: Elaboração do autor, 2017.

Outro elemento a ser ressaltado diz respeito à alimentação que é servida aos romeiros. As trabalhadoras e trabalhadores rurais, que, através da luta, estão assentados, fazem a doação desse alimento, que é produzido em suas terras, a partir de seu trabalho. Outros se unem e adquirem um boi, que é morto um dia antes do início da Romaria e é consumido durante todo o itinerário.

Uma caminhonete distribui água entre os romeiros, e dois caminhões, um transportando as bagagens e outro com a equipe responsável pelo preparo da alimentação, vão à frente e esperam os romeiros nos pontos de apoio, principalmente em comunidades de trabalhadores rurais e escolas. A alimentação servida é, basicamente, churrasco, feijão, arroz, salada e farinha de mandioca. O café da manhã é oferecido pelas comunidades de trabalhadores rurais, que se organizam para receber os romeiros. O que é servido no café da manhã varia de uma comunidade para outra, inclui do tradicional café com pão ao açaí com carne moída e farinha de mandioca.

A Romaria de 55 quilômetros tem início no município de Anapu, no Centro de Formação São Rafael, onde está sepultado o corpo de irmã Dorothy, e termina no Memorial Dorothy Stang, construído na entrada do PDS Esperança, idealizado pela Missionária e local do seu assassinato. Em seguida, é realizado o Forró da Dorothy, festa que celebra a chegada da Romaria. 
Figura 3 - Integrantes da Banda Vale no Forró da Dorothy.

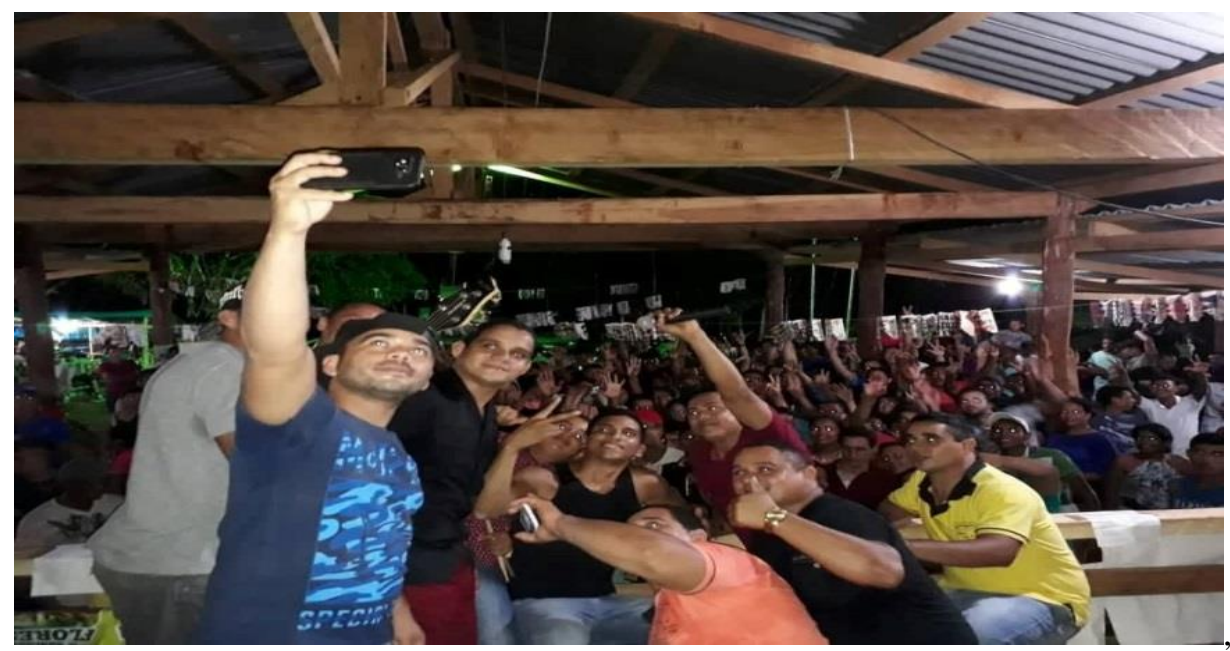

Fonte: Magno Leite, 2017.

Importante ressaltar que, na $10^{\mathrm{a}}$ edição da Romaria da Floresta, foi noticiado que o Memorial Dorothy Stang passaria a se chamar Memorial dos Mártires da Terra e da Floresta e uma placa, com o nome das pessoas que foram assassinadas em Anapu lutando pela reforma agrária, faria parte desse memorial. No entanto, verificou-se, durante o trabalho de campo, que essas alterações ainda não foram realizadas.

No quarto dia, o memorial é decorado com balões e produtos agrícolas produzidos nos PDSs e é celebrada uma missa, com liturgia característica da Teologia da Libertação. Uma homilia, ou seja, uma pregação religiosa-política (SANTOS, 2015), ao ar livre, em meio à floresta, norteia a missa de encerramento.

Figura 4 - Missa de encerramento em frente ao Memorial.

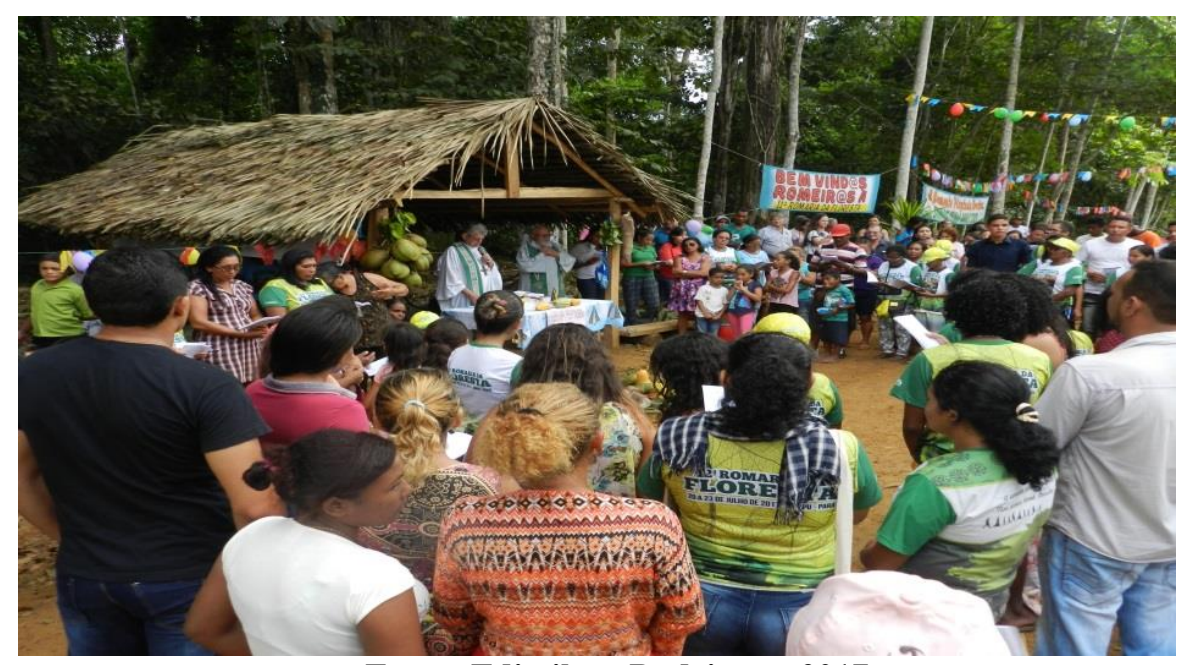

Fonte: Edimilson Rodrigues, 2017. 
Durante a peregrinação, ocorrem paradas onde, constantemente, é realizado o resgate da história de vida da Missionária, bem como o resgate de sua atuação na luta pela reforma agrária e por direitos. Segundo o material de divulgação da $12^{a}$ edição, essas paradas "são momentos místicos de reflexão e espiritualidade, fazendo memória das lutas de Dorothy e outros mártires, valorizando a cultura e a criatividade popular” (PASTORAL..., 2017).

\title{
A Dimensão política e RELigiosa da RoMARia da Floresta: ENQUADRAMENTO TEÓRICO, A IGREJA E OS PROBLEMAS DA TERRA
}

Os primeiros estudos envolvendo geografia e religião datam da primeira metade do século XX, no entanto, esses estudos nem sempre mereceram destaque no ambiente geográfico. Algumas iniciativas pioneiras fizeram com que a religião passasse a ser considerada um tema relevante nas pesquisas em geografia, mesmo que à margem da geografia clássica. Dentre essas iniciativas, é importante pontuar que:

\begin{abstract}
O interesse de alguns geógrafos pela análise das religiões no espaço social deu-se a partir do pós-guerra, à margem da Geografia Tradicional e suas correntes derivadas. Destacam-se as contribuições de Pierre Deffontaines (1948) com a obra Géographie et religions, que investigou as relações entre as culturas e suas representações religiosas concretas no espaço (igrejas, cemitérios etc.) e Maximilien Sorre (1955) no texto Géographie des activités réligieuses, onde abordou as atividades religiosas e suas influências no espaço social, sobretudo no meio rural (SANTOS, 2015, p. 60).
\end{abstract}

Um conjunto de fatores concorreu para que a geografia clássica não atribuísse a devida importância para estudos sobre religiões durante um longo período, fazendo com que essa temática ocupasse o subterrâneo da ciência geográfica. A esse respeito, o geógrafo francês Claval (2014) analisa da seguinte forma:

Se há um sentimento que não aflorava nunca na geografia clássica, era efetivamente o da sacralidade. $\mathrm{O}$ universo no qual se inscrevia era resolutamente prosaico, tratava de trabalho, de campos, de sebes e muros, de casas de pedra, de tijolo; falava do comércio. A geografia era uma ciência da seriedade e do permanente. Mencionava as igrejas ou os templos porque eram referenciais visíveis na paisagem, mas continuava a ser curiosamente silenciosa sobre os cemitérios, porque a vida é o que interessava, falava de turismo, mas não se voltava muito para as festas que frequentavam participantes estivais. [...] $\mathrm{O}$ horizonte em que se fixava era $\mathrm{o}$ econômico. Os lugares diferenciavam-se pela sua acessibilidade, sua distância, pelo preço de suas terras, pela presença de recursos ou de amenidades. Não tinham mais nada a dizer (CLAVAL, 2014, p. 232). 
Segundo o mesmo autor, o cenário começou a sofrer alteração com o aparecimento de um novo olhar geográfico, que irrompe no seio da ciência geográfica; assim, a importância dos estudos sobre a religião passa a se afirmar na geografia. De acordo com ele:

O novo olhar geográfico rompe com essa situação. Os critérios utilitaristas que prevaleciam no passado cessam de ser exclusivos. A experiência do religioso e do sagrado merece a mesma atenção que a cotidianidade laica. A consideração desse campo por muito tempo negligenciado é favorecida pela descoberta da obra de Mircea Eliade $(1963,1965,1971)$. [...] O impacto das reflexões do grande especialista romeno das religiões era perceptível desde o começo dos anos de 1950 (CLAVAL, 2014, p. 232).

A partir das observações citadas acima, vale referenciar a contribuição de Mircea Eliade para os estudos geográficos da religião, principalmente no que tange às definições de espaço sagrado e espaço profano. Para Mircea Eliade, "o sagrado irrompe em determinados lugares como revelações hierofânicas, tornando-os qualitativamente poderosos 'centros de mundos de significativos', separados do espaço comum, do cotidiano profano" (ROSENDAHL, 2014, p. 202).

$\mathrm{Na}$ obra "O sagrado e o profano", de Mircea Eliade, encontra-se destaque para as implicações provocadas pela manifestação hierofania no espaço. Segundo ele:

\begin{abstract}
A manifestação do sagrado no espaço tem, como consequência, uma valência cosmológica: toda hierofania espacial ou toda consagração de um espaço equivalem a uma cosmogonia. Uma primeira conclusão seria a seguinte: o Mundo deixa de se perceber como Mundo, como cosmos, à medida que se revela como mundo sagrado (ELIADE, 1992, p. 36).
\end{abstract}

Associado ao espaço sagrado está o espaço profano, que seria um espaço homogêneo e neutro, não possuindo nenhuma ruptura que os diferencia qualitativamente de suas outras partes (ELIADE, 1992). No entanto, o autor faz uma ressalva para o fato de que, mesmo nos limites do espaço profano, existirá um comportamento religioso. Ele frisa que:

[...] é preciso acrescentar que uma tal existência profana jamais se encontra no estado puro. Seja qual for o grau de dessacralização do mundo a que tenha chegado, o homem que optou por uma vida profana não consegue abolir completamente o comportamento religioso (ELIADE, 1992, p. 18).

Igualmente, fazem-se necessários para a compreensão do objeto da pesquisa os conceitos de religião e peregrinação. O ponto de partida será a definição conceitual de religião e peregrinação, no intuito de evidenciar as bases teóricas que nortearão a análise. Levando em Ferreira, 2019 ISSN 0104-5490 201 
consideração que a Romaria da Floresta é direcionada pela religião Cristã, em sua vertente Católica Apostólica Romana, e envolvida por um conjunto de representações materiais e simbólicas, pode-se, conceitualmente, definir que religião é:

A crença na existência de uma força sobrenatural, ou um poder espiritual superior à humanidade, considerado como criador do Universo, e que como tal deve ser adorado e obedecido. A palavra religião, segundo linguistas, deriva do vocábulo latino religare, que significa "tornar a ligar" ou religar. Daí a ideia popular de que a religião religa a humanidade à divindade superior, ou Deus. [...] Toda religião tem uma doutrina, ou princípios, que fundamenta a crença, ou fé, de seus adeptos ou seguidores. Pode se dizer que todas as religiões têm seu ritos, isto é, regras ou normas para a prática dos cultos. O culto é a manifestação simbólica de agradecimento ou homenagem à divindade (SANTOS, 2015, p. 85).

Outra definição que, intrinsecamente, está associada à categoria religião são as relações de poder. E, ao mesmo tempo, pode-se destacar que, historicamente, os estudos geográficos das religiões não deram a devida importância a essas relações de poder, concentrando-se, basicamente, em suas expressões espaciais. Segundo essa definiç̧ão:

\begin{abstract}
Do mesmo modo que a língua, a religião é um sistema sêmico cuja função é assegurar uma mediação. No momento não insistiremos na natureza e no conteúdo dessa mediação a não ser para dizer que os fatos religiosos não escapam da problemática relacional nem, muito menos, do poder, por consequência. No entanto, a geografia das religiões, ao mesmo tempo que fornece pontos úteis de referências, em geral deixou de lado as relações de poder para se concentrar, talvez excessivamente, nas expressões espaciais do fenômeno religioso. Sem dúvida é possível encontrar, nas diferentes geografias das religiões, preocupações relativas ao poder, mas não passam de pegadas que é preciso cercar aqui e ali. O fenômeno religioso não foi, ao menos para os geógrafos, concebido em termos de relações de poder. Em sua própria essência, o fenômeno religioso é bem caracterizado pelas relações de poder (RAFFESTIN, 1980, p. 19).
\end{abstract}

Além do viés político, é importante destacar outra faceta da religião: sua dimensão ideológica. No itinerário da Romaria, essa dimensão ideológica é marcante, está presente nas denúncias, nas análises da conjuntura local e nacional ou através do constante destaque dado à importância da atuação política para a transformação da realidade, para que se construa, aqui na Terra, uma vida plena e feliz. Assim:

Sendo a religião parte da cultura, ela também é ideologia. Cultura e ideologia caminham juntas, ou seja, não entendemos esses conceitos como contrários ou opostos entre si. Portanto, a nosso ver, religião pode ser entendida como alienação ou como libertação, dependendo do ponto de vista e de uma série de fatores históricos, políticos e sociais (SANTOS, 2015, p. 59). 
Umas das temáticas relevantes para o estudo geográfico da religião são as peregrinações. Antes de se destacar as características desse tipo de manifestação religiosa, é importante defini-la, conceitualmente e etimologicamente. O termo "peregrinação tem, em língua portuguesa, uma palavra afim - romaria; esta, significa a participação periódica numa festa religiosa local ou regional” (SANTOS apud RINSCHEDE, 1987, p. 382).

As peregrinações são consideradas, também, formas de migração humana que remontam a períodos imemoriais e que, ainda nos dias atuais, fazem parte da cultura de muitas sociedades. Nesse sentido:

A realização de peregrinações constitui um patrimônio cultural comum a muitos povos, caracterizando-se como uma forma típica de sua expressão religiosa em termos individuais e sociais. A peregrinação é uma das mais antigas formas de migração humana, estimulada por motivos não estritamente econômicos, provavelmente existe desde as religiões pré-históricas, e que se tornou uma realidade de relevância e impacto ainda mais notáveis com o surgimento dos grandes sistemas de crença (SANTOS, 2010, p. 147).

Esses deslocamentos motivados pela fé possuem uma incontestável dimensão espacial, pelo fato de implicar o deslocamento humano pelo espaço, um deslocamento físico e espiritual. Em muitos casos, o deslocamento obedece a uma periodicidade, envolvendo tempo e espaço fixos, ou seja, os lugares sagrados e, de outro lado, os fluxos, a peregrinação.

No âmbito do cristianismo, as peregrinações datam do século $\mathrm{V}$ e ficaram conhecidas como romarias, devido ao deslocamento dos devotos se dirigirem a Roma (ROSENDHAL, 1995). Elas possuem elementos que as caracterizam enquanto manifestações religiosas, presentes em várias sociedades. Esses elementos caracterizadores seriam os seguintes: movimento, motivação, destino, magnitude e distância (SANTOS, 2010).

A motivação de muitos movimentos humanos estaria ligada ao desejo de enriquecimento material ou busca de melhores condições de vida. Outros movimentos são motivados, total ou parcialmente, por questões espirituais, um caso clássico seriam as peregrinações. Dentro das motivações espirituais, que podem estar ligadas a questões de ordem material, o que motiva a peregrinação são pontos no espaço onde se manifesta o sagrado. Segundo a autora:

Os lugares de peregrinação se configuram, assim, como pontos do espaço onde tais forças sobrenaturais e divinas convergem e se manifestam, parecendo estar mais ao alcance de cada um. [...] Para além do impulso pessoal, a peregrinação, resultante muitas vezes de um propósito de regeneração espiritual, as próprias autoridades 
religiosas de cada santuário procuram normalmente favorecer essas deslocações por meio da propagação dos acontecimentos extraordinários ali ocorridos. [...] A peregrinação pode ainda ser vista como forma de penitência, sendo essa entendida como sansão de ordem espiritual, ou como meio de obter algum benefício ou prêmio [...] (SANTOS, 2010, p. 167-169).

Na Romaria da Floresta, a motivação dos romeiros está vinculada a uma pessoa, no caso, a Irmã Dorothy; porém, não se limita ao simbolismo construído em torno de sua imagem. Outro aspecto que motiva os romeiros a se deslocarem durante três dias no município de Anapu é o exercício da política, enquanto denúncia e instrumento de transformação social. Logo, o destaque dessa Romaria reside na diversidade de elementos que a constitui, tornando difícil se estabelecer comparações com romarias motivadas estritamente por questões espirituais. Outra especificidade da Romaria da Floresta está relacionada ao destino de seu itinerário, pois as peregrinações se dirigem:

\begin{abstract}
Normalmente é um lugar sagrado ou santo. Contudo, existem dificuldades na medição dessa qualidade e na hierarquização dos lugares com base nela, já que, em certos contextos religiosos, podem ocorrer peregrinações que têm como fator de atração não lugares, mas pessoas. No lugar de peregrinação, o motivo de atração é materializado de diferentes maneiras: pela presença de relíquias de santos, de túmulos, de ícones, de estátuas e outras formas de representação. Em outros casos, é aceito como fato histórico por parte dos crentes que se deu nesse local uma verdadeira explosão do sobrenatural, manifestada com aparições ou curas inexplicáveis, por exemplo (SANTOS, 2010, p. 171-172).
\end{abstract}

A Romaria realizada em Anapu não está vinculada a um lugar sagrado ou santo, ou seja, seu itinerário não conduz os peregrinos a um local onde ocorreu a manifestação do sagrado, a hierofania. Mas, para os romeiros, o sagrado está presente em todo o itinerário, junto às orações, místicas, missas e em uma natureza por vezes sacralizada na visão deles. Também é importante frisar que o itinerário da Romaria da Floresta conduz o movimento dos romeiros da cidade para o campo.

A Romaria também possui uma dimensão profana, que se manifesta em certas canções, no debate político, na festa e no consumo de bebidas alcoólicas, por exemplo. Outra peculiaridade da Romaria é a presença do debate socioambiental, presente nos discursos, canções e orações, onde é possível perceber a defesa de uma relação sociedade-natureza no lugar. 


\section{Revista de Geografia (Recife) V. 36, N.1, 2019}

Figura 5 - Centro de Formação São Rafael.

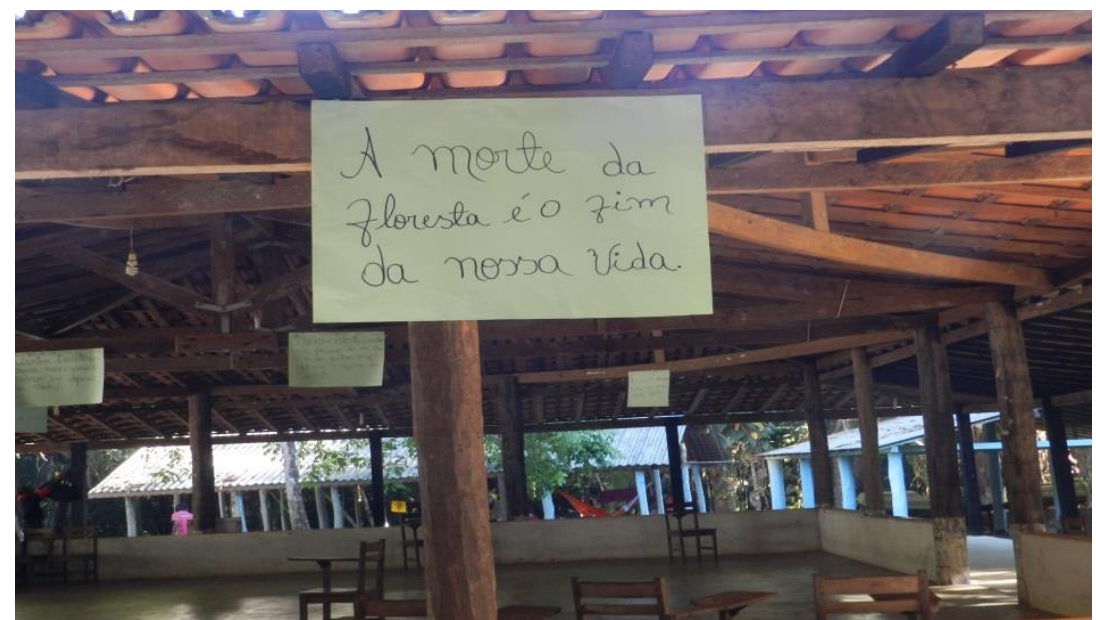

Fonte: Elaboração do autor, 2017.

A temática ambiental, da maneira como é abordada, está afinada com o discurso do desenvolvimento sustentável, com a manutenção de modos de vida e, por vezes, tende a operar na perspectiva de uma natureza sacralizada. E, no bojo desta visão sacralizada, está o incentivo a um modo de vida comunitário. A natureza enquanto criação divina para que as pessoas vivam em comunhão entre si e com a natureza.

É possível afirmar que se trata da "ambientalização" dos conflitos sociais. Conceitualmente, trata-se de um neologismo, utilizado nas ciências sociais, para fazer referência a novos fenômenos ou percepções de fenômenos que são vistos em uma perspectiva de processo, assim como as expressões "industrialização" e "proletarização" foram indicativos de novos processos no final do século XX (LOPES, 2006).

Os atores subalternizados no espaço agrário de Anapu, vinculados à CPT e a outras entidades com viés progressista, incorporaram a temática ambiental em suas pautas como estratégia para exigir do Estado políticas públicas. Dentre as demandas, estão: a regularização fundiária, o combate ao intenso desmatamento no município, a defesa dos modos de vida da população local e o combate às práticas dos atores ligados ao agronegócio, que ameaçam esse conjunto de relações que são estabelecidas entre o modo de vida das populações ruralistas.

Essa bandeira de luta se torna evidente nas consignas presentes na Romaria da Floresta, quando se afirma, por exemplo, que “A morte da floresta é o fim das nossas vidas". Desse modo, esse processo, denominado "ambientalização", acarreta uma interiorização de diferentes facetas à questão pública referente aos recursos naturais. A assimilação e a naturalização de uma nova questão pública podem ser notadas pelas transformações nas 
formas e nas linguagens dos conflitos sociais e na sua parcial institucionalização (LOPES, 2006).

No caso concreto, pode-se verificar a criação dos PDSs como incorporação institucional dessas novas práticas utilizadas pelos movimentos sociais no sentido de fixar, na esfera estatal, suas demandas. Os PDSs são considerados conquistas históricas por segmentos sociais de Anapu e esse aspecto é bastante ressaltado na Romaria. Portanto, “ambientalização" pode designar:

[...] tanto o processo de adoção de um discurso ambiental genérico por parte dos diferentes grupos sociais, como a incorporação concreta de justificativas ambientais para legitimar práticas institucionais, políticas, científicas etc. Sua pertinência teórica ganha, porém, força particular na possibilidade de caracterizar processos de ambientalização específicos a determinados lugares, contextos e momentos históricos. É por meio desses processos que novos fenômenos vão sendo construídos e expostos à esfera pública, assim como velhos fenômenos são renomeados como "ambientais", e um esforço de unificação engloba-os sob a chancela da "proteção ao meio ambiente". Disputas de legitimidade instauram-se, concomitantemente, na busca de caracterizar as diferentes práticas como ambientalmente benignas ou danosas. Nessas disputas em que diferentes atores sociais ambientalizam seus discursos, ações coletivas são esboçadas na constituição de conflitos sociais incidentes sobre esses novos objetos, seja questionando os padrões técnicos de apropriação do território e seus recursos, seja contestando a distribuição de poder sobre eles (ACSCELRAD, 2010, p. 103).

Pode-se afirmar, também, que a "ambientalização" das lutas sociais no município instrumentaliza críticas a ação de grileiros, fazendeiros, madeireiros e latifundiários no município, ou seja, de uma elite agrária. Nos dois primeiros dias de Romaria, quase não se verifica a presença da floresta na paisagem, fato bastante ressaltado no itinerário da Romaria.

Denunciam as atividades econômicas desenvolvidas pelos segmentos sociais citados acima, por serem concentradores de terras, predadores da natureza e por estarem voltados estritamente para o lucro. Apenas no terceiro dia de Romaria, quando se avista o PDS Esperança, é que a floresta se destaca na paisagem. 
Figura 6 - Área desmatada no itinerário da Romaria.

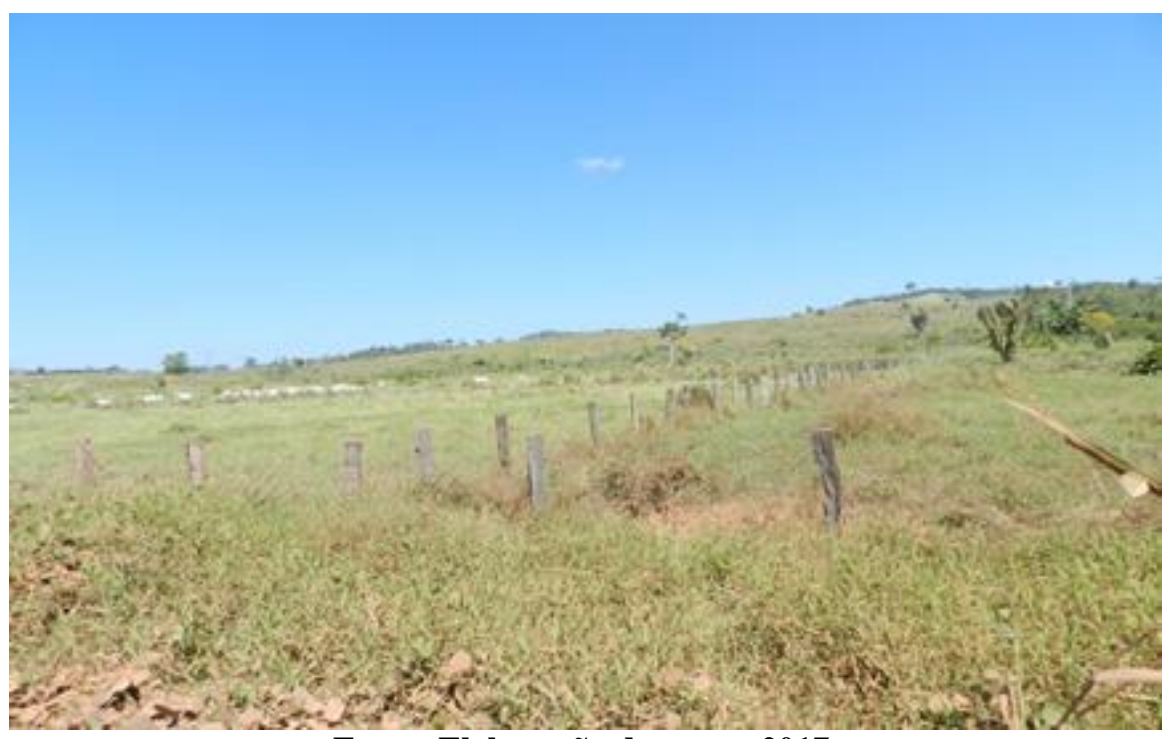

Fonte: Elaboração do autor, 2017.

Isso ressalta a dimensão política da Romaria, pois esta dimensão está presente na forma como a temática ambiental é abordada nas liturgias, na defesa da reforma agrária e da luta por direitos. A romaria em questão surgiu após um assassinato e seu itinerário termina no local onde este assassinato ocorreu, onde foi construído o memorial Dorothy Stang, na entrada do PDS Esperança.

\section{APRESENTANDO A ROMARIA: ATORES E TRAJETÓRIAS ESPACIAIS}

Nesta seção, foi realizada uma apresentação, com base na aplicação de um questionário semiestruturado, da composição social da Romaria da Floresta e da história de algumas trajetórias espaciais. A aplicação do questionário também objetivou captar os fatores que motivam os romeiros a participarem da peregrinação e o significado que a Romaria e a Missionária Dorothy Stang possuem para eles.

A composição social da peregrinação é marcada por diversos segmentos presentes no espaço agrário brasileiro, como posseiros, assentados, trabalhadores rurais, além de membros de diversas pastorais, como a Pastoral da Terra, Pastoral da Juventude, de Pescadores, CEBs (Comunidades Eclesiais de Base), entre outras. Também participam membros de diversas entidades, como MAB (Movimento dos Atingidos por Barragens), MST (Movimento dos Trabalhadores Rurais Sem Terra), sindicatos de trabalhadores rurais, evangélicos e aqueles 
que não possuem religião, que participam por motivação política ou pelo fato de terem convivido com a Irmã Dorothy Stang e criado vínculo afetivo.

As romeiras e romeiros possuem diversas trajetórias espaciais, que remetem à concentração fundiária no espaço agrário brasileiro, à expropriação e diversas formas de violência, mas também à luta pelo acesso à terra, direitos e identidade nos lugares pelos quais passaram. Durante a participação em duas edições desta Romaria, foi possível ouvir relatos que evidenciam diversas trajetórias espaciais que, obviamente, estão concatenadas às suas trajetórias de vida.

São migrantes de diversos lugares do Brasil, principalmente da Região Nordeste e Norte, forçados a realizar várias "peregrinações" em busca de uma vida cuja existência seja plena, sempre levando a esperança na bagagem. É pertinente que se dê o destaque para algumas trajetórias espaciais, em consonância com o significado que a Romaria e a Irmã Dorothy Stang possuem para esses peregrinos.

O nome dos entrevistados será ocultado devido à conjuntura conturbada na qual se encontra o município, sendo uma forma de resguardar os romeiros que responderam ao questionário. No lugar do nome, foram utilizadas alcunhas (esperança, luta, resistência etc.).

A primeira entrevista selecionada é a de um jovem, de 23 anos de idade, que nasceu em Altamira - PA e migrou, juntamente com sua família, por diversos municípios do Estado do Pará, como Vitória do Xingu, Brasil Novo e, por último, Castanhal, onde reside atualmente.

Quando perguntado a respeito das motivações que o fizeram migrar, destacou a necessidade de sua família conseguir emprego e, posteriormente, migrou sozinho para ter acesso à educação formal, como se observa:

Foi mais a família, questão de emprego do meu pai, né?

$\mathrm{E}$, quando fui para Castanhal, foi pelos meus estudos, que eu fui estudar lá (Romeira Esperança, entrevista realizada em julho de 2017).

A Romeira Esperança participou de três edições e, segundo ele, o que motivou sua participação na Romaria foi seu envolvimento com a Pastoral da Juventude. Em relação ao significado que a Romaria da Floresta possui para ele, fica evidente a dimensão política desta manifestação religiosa. Dimensão política que denuncia a violência no campo e reforça a necessidade de lutar por uma reforma agrária no município. Esta assertiva pode ser corroborada em sua resposta, quando descreve o que representa a Romaria da Floresta para ele: 
Representa um evento pra denúncia, pra memória, né? Tipo, porque a gente estando aqui, a gente denuncia várias coisas que acontecem que a mídia não mostra, né? E a gente continua a luta da Dorothy, a memória dela, né? A luta de tantos outros que morreram (Romeira Esperança, entrevista realizada em julho de 2017).

Em relação ao significado da Irmã Dorothy Stang, ele ressalta a forte atuação política da missionária no município, contrapondo-se à elite agrária local, mesmo sofrendo ameaças de morte. Representando, para ele, um exemplo de luta e força:

Não. Minha mãe conheceu ela. Minha mãe conheceu... A Irmã Dorothy representa luta, né? Força, Porque, mesmo ela estando ameaçada, ela continuou lutando, ela continuou indo pra cima dos latifundiários, né? Tanto que ela foi morta, né? Assassinada (Romeira Esperança, entrevista realizada em julho de 2017).

O Romeiro Resistência tem 45 anos de idade, nasceu no município de Bragança PA, reside na capital, Belém, e participou de cinco edições da Romaria da Floresta. O que motiva sua peregrinação é o fato de pertencer a um grupo missionário que atua no combate às injustiças sociais. Segundo ele, o grupo missionário do qual faz parte também atua na defesa da biodiversidade. Para ele, a Romaria representa um momento onde se desenvolve uma ação política pela preservação da natureza. Porém, ressalta que a manifestação religiosa e política é, também, um momento propício para estabelecer diálogo e conhecer pessoas. O romeiro destacou que:

Representa muito, porque é um momento não só da gente lutar pela preservação da natureza, mas, também, de conhecer outras pessoas e dialogar com elas, também (Romeiro Resistência, entrevista realizada em julho de 2017).

O Romeiro Resistência relatou que conheceu e atuou em certas missões populares ao lado da Missionária Dorothy Stang. Para ele, a Irmã Dorothy Stang representa uma mártir, que morreu defendendo os povos da floresta, afirmando, ainda, que:

Pessoalmente. Inclusive, eu participei de certas missões populares junto com ela. É uma mártir. Uma pessoa que morreu em defesa dos povos da floresta (Romeiro Resistência, entrevista realizada em julho de 2017).

A terceira entrevista selecionada foi a de uma jovem, de 28 anos de idade, que nasceu em Marabá - PA, reside em Anapu desde os sete anos de idade e participou de 10 edições da Romaria. Filha de trabalhadores rurais, possui, em sua trajetória espacial, a busca por 
educação formal fora do Estado do Pará. Posteriormente, retornou ao município de Anapu, para exercer a profissão de professora de geografia na área rural do município, como segue o relato abaixo:

Eu nasci em Marabá. Com sete anos, eu vim pra Anapu, vim morar no Pilão Poente 1(assentamento), com meu pai, na zona rural. Depois, eu morei até os 17 anos na zona rural e estudei, cursei até o sétimo ano, aí, com 17 anos, fui terminar o meu ensino fundamental no Goiás, em Itapuranga, fui embora. Lá, eu concluí o Fundamental, o Médio e fiz a faculdade de Geografia, me formei. Concluí meu curso de Geografia na UEG, de Goiás. E, depois, voltei, ano passado (2016), em dezembro, pra cá e voltei à minha origem, né? Fui trabalhar e, hoje em dia, trabalho como professora na (CFR) Casa Família Rural de Anapu (Romeira Luta, entrevista realizada em julho de 2017).

No que tange aos motivos que a fazem participar da Romaria, ela ressalta o contato com pessoas e ideias diferentes, além de ser um momento propício para interação com os movimentos sociais que compõem a Romaria. Também faz referência ao legado da Missionária Dorothy Stang na defesa da reforma agrária no município, pois afirmou que:

\begin{abstract}
A motivação, tipo assim, ter contato com outras pessoas, e conhecer outras pessoas, outras ideias. Ter esse contato com o movimento social. Estar ligada nesses assuntos: conflitos agrários, terra. Essa luta, né? Que a Irmã Dorothy deixou, né? E, tipo assim, é um abraço em todos, né? Nessa causa. Pra, né? Pra gente manter o que ela deixou. Ela deixou muitos frutos nessa terra e estamos lutando, né? Por uma reforma agrária digna pra nosso povo. O povo da terra (Romeira Luta, entrevista realizada em julho de 2017).
\end{abstract}

Em relação ao significado que a Romaria possui, a mesma mencionou que representa a continuidade da luta por uma reforma agrária, moradia e preservação da floresta. Uma forma de levar adiante a luta da irmã Dorothy Stang e de outros atores sociais no município. A dimensão política da Romaria aparece, novamente, como motivação para a peregrinação, bem como a necessidade de manter a luta por reforma agrária e direitos sociais. Segundo a entrevistada, a Romaria é:

A manutenção da luta, a floresta em pé, que as pessoas tenham uma morada digna pra viver, né? Sem conflitos pro nosso povo, o povo da terra. Lutamos por esse direito, pra cada pessoa ter direito à terra, que a terra não fique na mão de uma só pessoa e uma terra ficar improdutiva. Ela tem que produzir. A terra é pra isso, pra produzir. E terra pra quem não tem. Então, eu vejo mais isso, a bandeira que a Irmã Dorothy erguia, que é o povo atrás de moradia pras pessoas que não tinham e manter a nossa floresta, né? De pé. Trabalhando de forma harmoniosa com ela (Romeira Luta, entrevista realizada em julho de 2017). 
A Romeira Luta e sua família possuíam um estreito vínculo com a missionária, que foi, inclusive, responsável por assentar sua família em Anapu. A missionária frequentava sua casa e era uma espécie de conselheira que, dentre outras coisas, incentivou-a nos estudos, para que pudesse contribuir com a comunidade posteriormente. Para ela, a Irmã Dorothy não foi apenas uma liderança dos movimentos sociais de Anapu, foi uma "anja" da floresta amazônica, afirmando que:

Conheci a Irmã Dorothy. Quando eu vim pra cá, ela que colocou no assentamento, ela deu lote pro meu pai, colocou a gente nesse lote, que é o Poente 1. Então, a gente tinha muito contato com a Irmã Dorothy, tipo, ela conversava muito com o meu pai, eu era muito pequena, então não entendia muita coisa que ela falava, né? Só hoje eu consigo entender um pouco, da trajetória da vida dela. E, aí, eu lembro que ela dormia em casa, fazia reunião com a comunidade, é, dava muito conselho pro meu pai. Falava assim pro meu pai: "Seu Manél, tem que lutar pros seus filho estudar, e, depois de estudado, voltar às raízes, pra ajudar o nosso povo", ou seja, eu estudar, voltar ou como a professora ou como médico ou como engenheiro florestal, mas trabalhar na terra, juntamente com a comunidade. Ah, a Irmã Dorothy, ai, ela significa... É uma líder pra mim. Ela foi uma grande líder, ela pra mim é uma... Uma... Uma anja. Uma anja da Floresta Amazônica. Pra mim, ela representa isso. E foi uma grande líder. Que conseguiu liderar, fazer uma grande liderança nessa região, e, também, ela deixou sucessores dela. Porque um grande líder, ele deixa sucessores. Ela foi embora - ela sabia que ela ia embora -, mas ela deixou pessoas pra levantar essa bandeira (Romeira Luta, entrevista realizada em julho de 2017).

Outra entrevistada foi a Romeira Organização, uma senhora de 62 anos de idade, que, na Romaria da Floresta, destaca-se por seu carisma e alegria. Assentada do PDS Esperança, a romeira participou e ajudou a organizar todas as edições da Romaria da Floresta. Migrou do Estado do Maranhão para a Amazônia em busca de "melhoria". Chegou ao Pará em 1984 e, há 13 anos, está assentada em um dos PDSs. Para ela, a Romaria da Floresta:

[...] representa muita coisa boa: a paz, o silêncio, o amor, a fartura. Ela representa muita coisa. A natureza muito bonita, a floresta, ela é um... Aqui, você recebe um ar puro, aqui, dentro. Sei que aqui não tem poluição nenhuma, então, ela pra mim, ela me representa muita coisa boa (Romeira Organização, entrevista realizada em julho de 2017).

A esperança, a paz, a união e a luta da Irmã Dorothy são as principais motivações de sua peregrinação na Romaria da Floresta. Quando questionada sobre sua motivação, respondeu:

O motivo? Ah, o que motiva é aquela... Aquela esperança, né?, aquela luta que a Irmã Dorothy deixou pra nós, né?, e a Romaria, ela traz, assim, um impacto muito bom na vida, na nossa vida, aqui dentro, num sabe? Traz, ela traz uma grande força pra nós, aqui, da união, da paz, assim (Romeira Organização, entrevista realizada em julho de 2017). 
Nas conversas informais com romeiras e romeiros durante a execução do trabalho de campo, foi recorrente ouvir a designação "mãe" quando se referiam à Missionária. Logo em seguida, narravam sua gratidão, em decorrência de alguma ação da Missionária em momentos de dificuldades. Foram diversas narrativas que citaram a atuação da Missionária, que perpassam pelo acolhimento de famílias que migraram para Anapu até o apoio que dispensava às pessoas em caso de doenças. Aqui, a designação "mãe" aparece novamente, no relato que segue:

[...] Oh, ela significa, pra mim, uma mãe. Ela era mais do que uma mãe pra mim. Aliás, não só pra mim, mas pra todos nós, agricultor, aqui, dentro. Porque ela lutou por nós, aqui, dentro, pra adquirir esse pedaço de terra pra cada um de nós, e terminou dando a vida dela em prol dessa terra. (Romeira Organização, entrevista realizada em julho de 2017).

Durante o trabalho de campo, realizado em 2017, foi possível entrevistar o Romeiro Ação Direta, senhor de 51 anos de idade e grande liderança da CPT no município. Migrou do Maranhão para o Estado do Pará e, nos anos de 1990, foi atuar na Transamazônica, fixando-se em Anapu. Para ele, a Romaria da Floresta representa a junção entre atuação política, que defende a reforma agrária e a floresta, e celebração, afirmando que:

Olha, pra mim, representa um sinal de luta, resistência e persistência. É a gente trazer a memória dos mártires, especialmente essa mártir, Dorothy Stang, que ela morreu defendendo o direito à terra, a floresta e a natureza. Então, pra nós, celebrar a décima segunda Romaria da Floresta representa um sinal de resistência, luta e celebração (Romeiro Ação Direta, entrevista realizada em julho de 2017).

Em relação à Irmã Dorothy Stang, o Romeiro Ação Direta destaca a importância da Missionária para a sua formação e engajamento na Comissão Pastoral da Terra. E, novamente, a designação "mãe” reaparece, como uma forma de expressar sua gratidão:

A irmã Dorothy significa, pra mim, uma mãe, né? Até mesmo porque eu morava no Movimento Missionário São Cristovão, lá em Belém, no Bairro do Guamá. Padre Sevino Manbelli, depois o [...] veio e achou que esse movimento não serviria para a formação de padres, porque nós tinha pessoas leigos [sic], lá, ali, também, estudando, e, então, achou que esse movimento não servia. Eu praticamente estava fora do seminário, pra conhecer, me trouxe, aqui, pra conhecer a área pastoral e, aí, me acompanhou na formação e me colocou dentro do movimento, dentro da própria CPT, né?, que é a Comissão Pastoral da Terra, e, aí, representa, pra mim, uma mãe (Romeiro Ação Direta, entrevista realizada em julho de 2017). 
Após o relato da diversa composição social da Romaria, é hora de mergulhar nas místicas e simbolismos, que estabelecem um diálogo intenso com a política, com a resistência e sonhos de mulheres e homens por uma vida digna na Fronteira Amazônica. Essas práticas chamaram a atenção do pesquisador desde o contato primário com o evento e, sem dúvida, são elas que tornam a Romaria da Floresta uma manifestação religiosa singular.

\section{CONCLUSÃO}

A Romaria é uma manifestação religiosa e política que possui uma riqueza de manifestações da cultura no espaço que percorre em seu itinerário. Além disso, as formas e lugares simbólicos onde são realizadas as místicas estão relacionados com as resistências do campesinato no espaço agrário do município e com a história de vida e de morte da Missionária Dorothy Stang. A percepção dos romeiros em relação à Romaria e à Irmã Dorothy Stang aponta para o seu viés político, enquanto uma manifestação que articula a fé e a organização da resistência. Aponta também para a importância do trabalho religioso e político desenvolvido pela Missionária no município.

O respectivo trabalho permitiu a construção inicial de algumas conclusões. A primeira é de que a Romaria da Floresta contribui para o processo de resistência do campesinato em Anapu, dando visibilidade nacional e internacional para os conflitos fundiários e socioambientais no município, e por representar, também, um momento de debates políticos e articulações de resistências durante os três dias de peregrinação. A manifestação religiosa e política é, também, uma estratégia importante para a manutenção de uma territorialidade histórica construída, no município, pela Igreja Católica Apostólica Romana.

\section{REFERÊNCIAS BIBLIOGRÁFICAS}

ACSELRAD, H. Ambientalização das lutas sociais - o caso do movimento por justiça ambiental. Estudos Avançados., São Paulo, v. 24, n. 68, p. 103-119, 2010. Disponível em: <https://www.researchgate.net/publication/250982734_Ambientalizacao_das_lutas_sociais__O_caso_do_movimento_por_justica_ambiental>. Acesso em: 13 mar. 2018.

BOFF, L. Ecologia, mundialização, espiritualidade. Rio de Janeiro: Record, 2008.

CADERNO de Canções da 10ª Romaria e CEBs. Anapu, Pará, 2015. 
CLAVAL, Paul Charles Christophe. Epistemologia da Geografia. 2. ed. Florianópolis: Editora da UFSC, 2014.

COMISSÃO PASTORAL DA TERRA. Disponível em: <https://www.cptnacional.org.br/ romarias $\geq$. Acesso em: 4 fev. 2018.

. Livro de Cantos da $12^{a}$ Romaria da Floresta. Anapu, Pará, 2015.

CORRÊA, R. L. Monumentos, política e espaço. In: CORRÊA, R. L.; ROSENDAHL, Z. (Org.). Geografia Cultural: uma antologia. Volume II. Rio de Janeiro: EdUERJ, 2013.

ELIADE, M. O profano e o sagrado. São Paulo: Martins Fontes, 1992.

LOPES, J. S. L. Sobre processos de "ambientalização" dos conflitos e sobre dilemas da participação. Horiz. Antropol., Porto Alegre, v. 12, n. 25, p. 31-54, jan./jun. 2006.

PJX CONVOCA a Juventude para a $12^{\text {a }}$ Romaria da Floresta. Blog Pastoral da Juventude, 1 jun. 2018. Disponível em: <http://pjdoxingu.blogspot.com/2017/06/pastoral-da-juventude-doxingu-se.html\#>. Acesso em: 17 maio 2017.

RAFFESTIN, Claude. Por uma geografia do poder. São Paulo: Ática, 1980.

ROMARIAS da terra e água. Portal da Comissão Pastora da Terra, Goiás, 2018. Disponível em: <https://www.cptnacional.org.br/romarias $\geq$. Acesso em: 4 fev. 2018.

ROSENDHAL, Zeny. Espaço, cultura e religião: dimensões de análise. In: CORRÊA, R. L.; ROSENDHAL, Z. (Org.). Introdução à Geografia Cultural. 6. ed. Rio de Janeiro: Bertrand Brasil, 2014.

. Geografia e religião: uma proposta. Espaço e Cultura, Rio de Janeiro, v. 1, n. 1, p. 45-74, 1995.

SANTOS, A. P. dos. Geopolítica das Igrejas e anarquia religiosa no Brasil: por uma geoética. 1. ed. Rio de Janeiro: Gramma, 2015.

SANTOS, M. G. M. P. Conhecimento Geográfico e Peregrinações: contributo para uma abordagem teórica. In: ROSENDHAL, Z. (Org.). Trilhas do sagrado. Rio de Janeiro: EdUERJ, 2010. 